\title{
Condylura (Mammalia, Talpidae) reloaded: New insights about the fossil representatives of the genus
}

\author{
Gabriele Sansalone, Tassos Kotsakis, and Paolo Piras
}

\begin{abstract}
The star nosed mole, Condylura cristata, due to its morphological and behavioural peculiarities, has been deeply investigated by different authors. By contrast, very little is known about the phylogenetic relationships, evolution and diversity of the fossil members of this genus. In the present study we provide new insights about the fossil specimens ascribed to Condylura taking into account systematic, palaeobiogeographical and palaeoecological aspects. Further, we provide a re-description of a fossil Condylura from the middle Miocene of Kazakhstan. We confirm that the Kazakh fossil belongs to the genus Condylura, based on humeral morphological features, and we discuss its implications and impact on the phylogenetic scenario and ecology of this peculiar talpid genus. This specimen represents the earliest record of the genus, thus suggesting an Eurasiatic origin instead of the most commonly accepted scenario of a North American one. The presence of both plesiomorphic and apomorphic characters in Condylura strongly supports the hypothesis that this genus could be considered as sister clade of Talpinae.
\end{abstract}

Gabriele Sansalone. Roma Tre University of Rome, Dept. of Sciences, L.S. Murialdo, 1 - 00146 Rome, Italy/Center for evolutionary ecology, C.da Fonte Lappone, Pesche, Italy/Form, Evolution and Anatomy Research Laboratory, Zoology, School of Environmental and Rural Sciences, University of New England, Armidale, NSW 2351, Australia gsansalone@uniroma3.it

Tassos Kotsakis. Roma Tre University of Rome, Dept. of Sciences, L.S. Murialdo, 1 - 00146 Rome, Italy/ Center for evolutionary ecology, C.da Fonte Lappone, Pesche, Italy kotsakis@uniroma3.it

Paolo Piras. Center for evolutionary ecology, C.da Fonte Lappone, Pesche, Italy/Dipartimento di Scienze Cardiovascolari,Respiratorie, Nefrologiche, Anestesiologiche e Geriatriche, "Sapienza" University of Rome, Rome, Italy/Dipartimento di Ingegneria Strutturale e Geotecnica, "Sapienza" University of Rome, Via Eudossiana 18, 00100, Rome, Italy ppiras@uniroma3.it

Keywords: Talpidae, humerus, systematics, Miocene, palaeobiogeography, palaeoecology

Submission: 15 February 2016 Acceptance: 29 November 2016

Sansalone, Gabriele, Kotsakis, Tassos, and Piras, Paolo. 2016. Condylura (Mammalia, Talpidae) reloaded: New insights about the fossil representatives of the genus. Palaeontologia Electronica 19.3.54A: 1-16 palaeo-electronica.org/content/2016/1716-condylura-fossil 


\section{INTRODUCTION}

The extant star nosed mole, Condylura cristata Illiger, 1811, shows a series of unique features among mammals. It is an accomplished diver and frequents tunnel systems excavated along the edges of streambeds and lakes relying on aquatic insects and annelids for a substantial proportion of its diet (Hamilton, 1931; Rust, 1966; Mclntyre et al., 2002). Condylura cristata is the sole extant representative of the genus and of the tribe Condylurini (Hutterer, 2005). This species possesses 22 fleshy and mobile appendages that surround the nose (Figure 1). These appendages are unique not only in their star-like appearance but also in their function. The star functions much like a tactile eye (Eimer, 1871), with a small but high-resolution pair of central appendages and a number of larger, lowresolution peripheral appendages (Catania, 1995; Catania and Kaas, 1996; Catania et al., 1999). Condylura cristata is an endemic North-American species, it occurs throughout much of North-Eastern United States and Eastern Canada (Petersen and Yates, 1980). In the northern part of its recent distribution it is found from extreme Eastern Manitoba and Minnesota to as far northeast as Labrador and Nova Scotia. The species ranges south-eastward through Wisconsin, Ohio and northern Indiana. Along the Atlantic coast as far as southeastern Georgia and in the Appalachian moun- tains, to eastern Tennessee and western North Carolina (Petersen and Yates 1980). Despite the presence of an abundant literature about life history of the extant C. cristata (Hamilton, 1931; Hickman, 1984; Gould et al., 1993; Catania et al., 1999; Campbell et al., 2000; Mclntyre et al., 2002; Catania, 2012a; Signore et al., 2012; Marzban et al., 2014; among others), the past diversity of this genus is poorly known. Condylura fossils were found at the New Paris sinkholes near Bedford, Pennsylvania. These remains trace back to the late Pleistocene ( $\sim 11$ ky; Guilday et al., 1964). Other Condylura fossils were recovered from Virginia, West Virginia, Maryland, Tennessee, and Missouri localities and trace back to the middle Pleistocene ( 700 ky; Parmalee et al., 1969; Guilday, 1979; Gunnell et al., 2008). All these specimens were referred to the extant species C. cristata (Gunnell et al., 2008). Skoczeń (1976) described two additional species belonging to the genus: Condylura kowalskii Skoczeń, 1976 and Condylura izabellae Skoczen, 1976 from the Polish Pliocene localities of Węże 1 and Rębielice Królewskie $1 \mathrm{~A}$ and 2. Skoczeń (1976) reported these species as the first records of condylurine moles in the Old World, hypothesizing that the North-American Condylura are descendants of European immigrants. Hutchinson (1984) reported the presence of cf. Condylura $\mathrm{sp}$. from the locality of Malheur River, Oregon (USA). Two formations, Mascall and Rattlesnake,

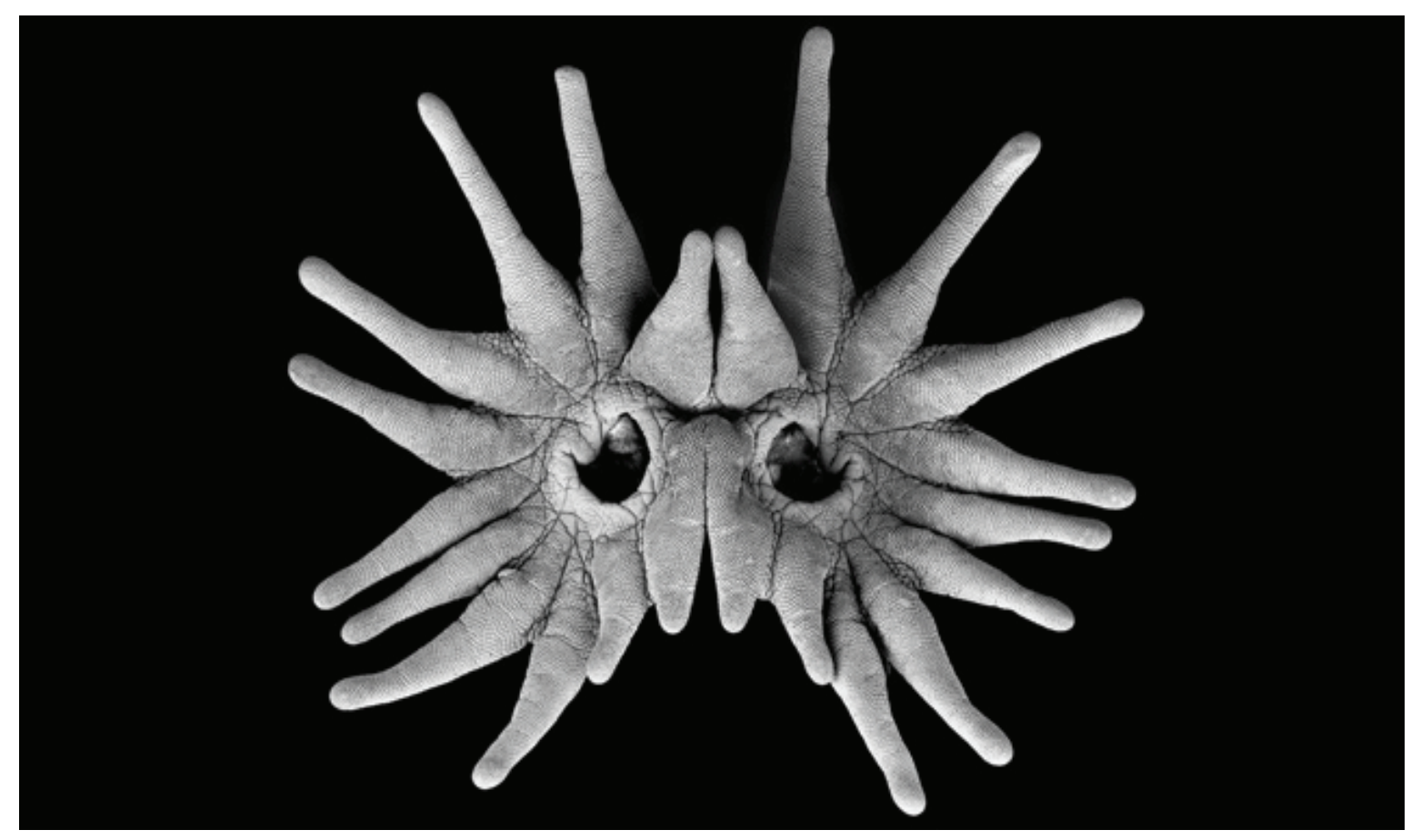

FIGURE 1. A detail of the star-like appendages from a preserved specimen. Image modified from Catania (2012b). 
are exposed in that area. Mascall formation is dated to middle Miocene (14-15 m.y.a., Barstovian), while Rattlesnake formation is dated to the late Miocene (Hemphillian, 7.5 m.y.a). Hutchinson (1984), basing on the lesser degree of mineralization of the bone, on its lighter coloration and on the museum label, suggested this specimen to be from the Rattlesnake formation. Further, Gunnell et al. (2008) accepted the original stratigraphical attribution by Hutchinson (1984).

He described a humerus that resembles in all of its features to that of the extant C. cristata. Hutchinson (1984) considered it as the earliest record for the genus and indicates a broader distribution for this taxon in the past. However, Lychev (1963) ascribed a humeral fragment from Kalkaman Lake, Pavlodar Priirtysch locality (Kazakhstan) to Condylura sp. Lychev (1963) attributed the Kalkaman Lake fauna to the late Miocene or early Pliocene, but different authors reported an older stratigraphic placement (middle Miocene; Tleuberdina, 1989; Tleuberdina et al., 1993; Tleuberdina and Forsten, 2001; Mirzaie Ataabadi et al., 2013). In particular, Tleuberdina and Forsten (2001) dated the fauna from Kalkaman Lake to the early Sarmatian or Late Astaracian mammal age equivalent (MN8; 11.9-11.1 m.y.a.). Hence, the specimen described by Lychev (1963) should be considered as the earliest record of Condylura. However, this record has been apparently unnoticed since the vast majority of the authors that discussed the problem of Condylura origin did not consider this finding (Skoczeń, 1976, 1993; Hutchinson, 1984; Sánchez-Villagra et al., 2006; Rzebik-Kowalska, 2014), while this record has been cited in fossil mammalian lists (McKenna and Bell, 1997; Gunnell et al., 2008).

The biogeography of Condylura is still debated. Achlyoscapter longirostris Hutchinson, 1968 (middle Miocene of Oregon and late Miocene of Nebraska, Bown, 1980) is the sole extinct genus tentatively ascribed to the tribe Condylurini. Hutchinson $(1968,1984)$ suggested this genus as the possible ancestor of Condylura basing on its brachyodont, non specialized and complete dental series. However, Hutchinson (1984) pointed out that the specialization present in the incisors and premolars of Condylura is not visible in Achlyoscapter remains. Rzebik-Kowalska (2014) highlighted that it is still uncertain whether Condylura originated in North America and then spread to Europe or vice versa. Possibly, it colonized North America from Europe via Asia.
The phylogenetic position of the genus represents another enigma; Condylura has been considered as a basal clade in Talpidae phylogeny, being placed as sister clade of uropsilines, desmans and shrew-moles (Hutchinson, 1976; Yates and Moore, 1990; Whidden, 2000; Shinohara et al., 2003; Motokawa, 2004; Cabria et al., 2006; Piras et al., 2012; Crumpton and Thompson, 2013). However, in the last decade, different authors, basing on morphological cladistic approaches, revealed closer affinities between Condylura and the highly fossorial moles (Sánchez-Villagra et al., 2006; Schwermann and Thompson, 2015). Here, we re-examine, from literature, the fossil material described by Lychev (1963), and we provide new evidences helping to unravel the debated phylogenetic relationships of Condylura. We also contribute to better understand the origin of the fossorial lifestyle. Finally, we provide new insights about the paleobiogeography and paleoecology of the genus.

\section{MATERIAL AND METHODS}

\section{Material}

Unfortunately, we did not have the ability to directly access the fossil material and to report the accession number and the exact location of the fossil material described by Lychev (1963). The material reported by Lychev (1963) has not been inventoried, and there is no possibility to contact the personnel that curated the material in past years (Tleuberdina, personal commun., 2015). Further, the Condylura sp. material was not housed in the Institute of Zoology, Laboratory of Paleozoology, National Academy of Sciences, Almaty, Kazakhstan, since it was not included in successive studies performed on vertebrate fossil material from Kalkaman locality (Tleuberdina, 1988, 1989; Tleuberdina et al., 1993; Tleuberdina and Forsten, 2001). See Figure 2 for the anatomical terminology. See Appendix for the complete list of the specimens used for comparisons.

\section{Institutional Abbreviations}

ISEZ-PAN: Institute of Systematics and Evolution of Animals, Krakow, Poland; IVPP: Institute of Vertebrate Paleontology and Paleoanthropology, Beijing, China; NHMA: Natural History Museum Augsburg, Augsburg, Germany; NHMW: Natural History Museum Wien, Wien, Austria; UO: University of Oregon, Oregon, USA; YPM: Yale Peabody Museum, New Haven, Connecticut, USA. 


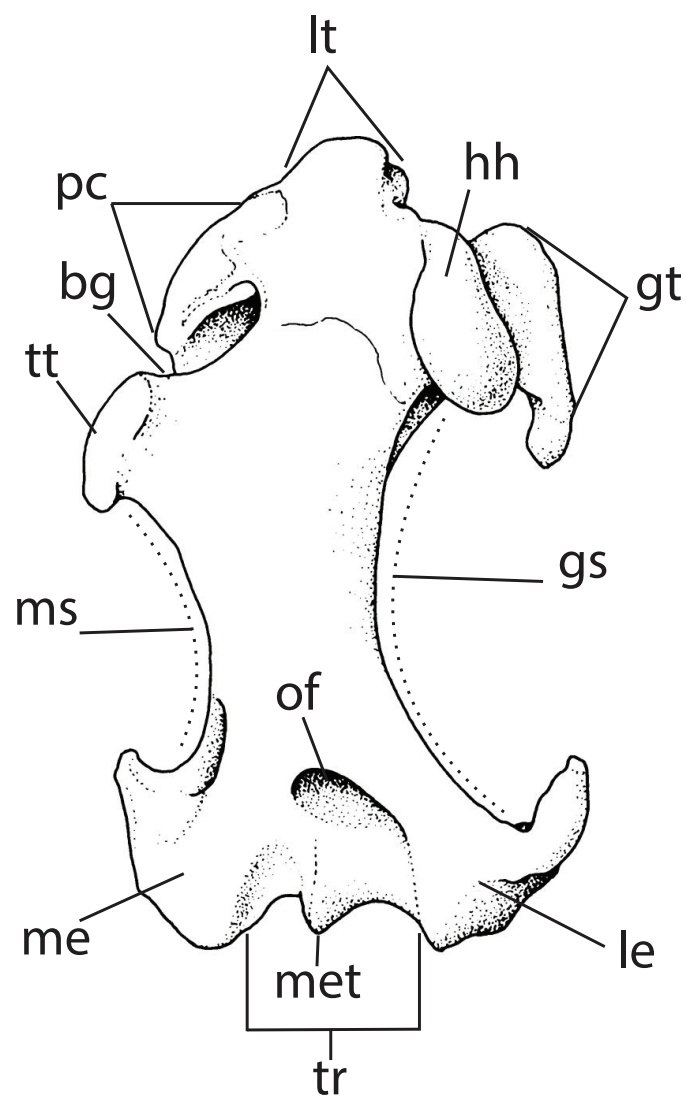

FIGURE 2. Drawing of a left humerus of Condylura cristata showing the anatomical terms used in this study (modified from Hutchinson, 1984). Abbreviations: bg, bicipital groove; gt, greater tuberosity; gs, greater sulcus; hh, humeral head; le, lateral epicondyle; It, lesser tuberosity; me, medial epicondyle; met, medial edge of the trochlea; ms, minor sulcus; of, olecranon fossa; pc, pectoral crest; tr, trochlea; tt, teres tubercle.

\section{SYSTEMATIC PALAEONTOLOGY}

Class MAMMALIA Linnaeus, 1758

Order EULIPOTYPHLA Waddel, Okada, Hasegawa, 1999

Family TALPIDAE Fischer von Waldheim, 1814

Subfamily TALPINAE Fischer von Waldheim, 1814

Tribe CONDYLURINI Gill, 1875

Genus CONDYLURA Illiger, 1811 Condylura sp.

1963 Condylura sp.; Lychev, p. 13, figs 1A, 1a.

1997 Condylura sp.; McKenna and Bell, p.282.

2008 Condylura sp.; Gunnel, Bown, Hutchinson, and Bloch, p. 103.

\section{Material}

Sample. 1 left humeral fragment Locality. Kalkaman Lake, Kazakhstan
Age. mammal age equivalent MN8; 11.9-11.1 m.y.a.

Horizon. Early Sarmatian or Late Astaracian mammal age equivalent (MN8; 11.9-11.1 m.y.a.).

\section{Description}

Humeral fragment (Figure 3.1-2). Maximal width of distal region: $8.5 \mathrm{~mm}$; width of the humeral shaft: $3.6 \mathrm{~mm}$. The proximal part is lost and the humeral head is not preserved. The capitulum is also broken. The fossa for flexor digitorum profundus is round and deep. The supracondylar foramen is wide and triangular in shape. The humerus shows a torsion of the shaft as occurs in fossorial moles. The distal part of the pectoral crest is slightly pronounced. Enlarged distal region of the humerus with the medial edge of the trochlea placed in the middle of the trochlear area. The greater sulcus is wide.

\section{New Diagnostic Feature}

Position of the medial edge of the trochlea and humeral shaft width. The medial edge of the trochlea is positioned in the middle of the trochlea in the shrew-moles (Urotrichini, Neurotrichini and Scaptonyx) while all highly fossorial moles (Talpini and Scalopini) have it medially displaced. Nevertheless, the humeral shaft of the highly fossorial talpids is more robust than that of the shrew-moles.

This genus-diagnostic character was detected among humeral material from both shrew-moles and true-moles (Hutchinson, 1968; Hutchinson, 1974; Ziegler, 2003; Sánchez-Villagra et al., 2004; Piras et al., 2012; Piras et al., 2015; Schwerman and Thompson, 2015; Sansalone et al., 2016).

\section{Comparisons}

We excluded from the comparisons all the robust highly fossorial moles (i.e., Talpini and the more robust Scalopini) due to the evident difference in the overall robustness of the humeral shaft. Furthermore, the Kazakh specimen is more robust than all the shrew-moles (Urotrichini and Neurotrichini); therefore we did not include these taxa in the comparisons. We compared the mole from Kalkaman Lake with all the Neogene less robust Scalopini and with the other described Condylura species.

cf. Condylura sp. The specimen from Kalkaman Lake differs from the cf. Condylura sp. from Hemphillian of Oregon (Hutchinson, 1984) in having a reduced minor sulcus. The two specimens are identical in the humeral distal region morphology. They share the triangular supracondylar fora- 

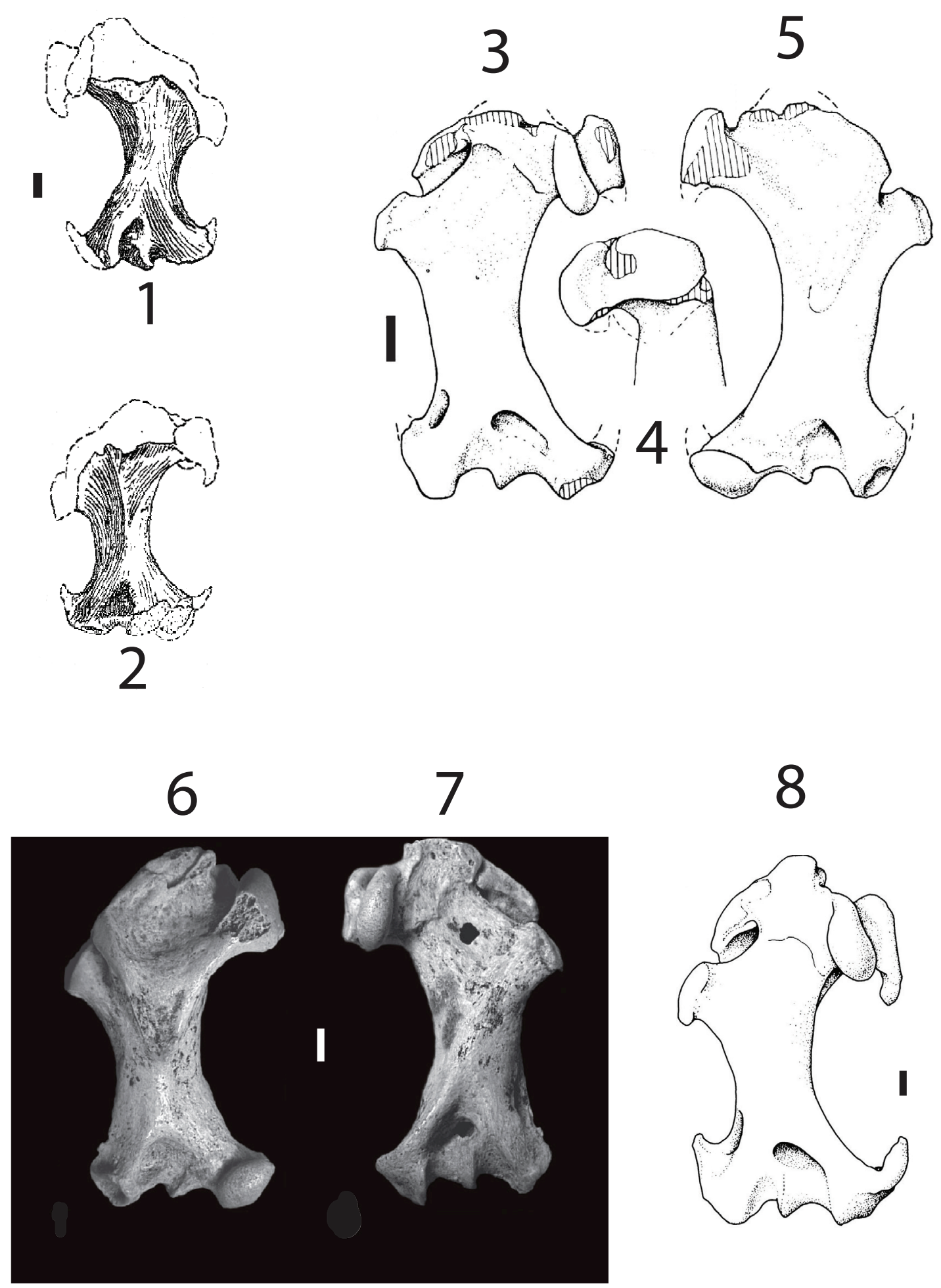

FIGURE 3. Drawings (1-5, 8) and photographs (6 and 7) showing fossil and extant representatives of genus Condylura. 1 and 2, Condylura sp., left humerus in caudal (1) and frontal (2) views, modified from Lychev (1963). 3-5, cf. Condylura sp., right humerus (YPM 20699, YPM) in caudal (3) and lateral (4) views and close-up of the greater tuberosity in medial view (5), modified from Hutchinson (1984, figure 1B). 6 and 7, Condylura kowalskii, left humerus (MF/ 1006/16, ISEZ-PAN) in frontal (6) and caudal (7) views, modified from Rzebik-Kowalska (2014, figure 2.1, 2.2). 8, Condylura cristata, right humerus in caudal view, modified from Hutchinson (1984, figure 1A). Scale bars represent 1 $\mathrm{mm}$. 

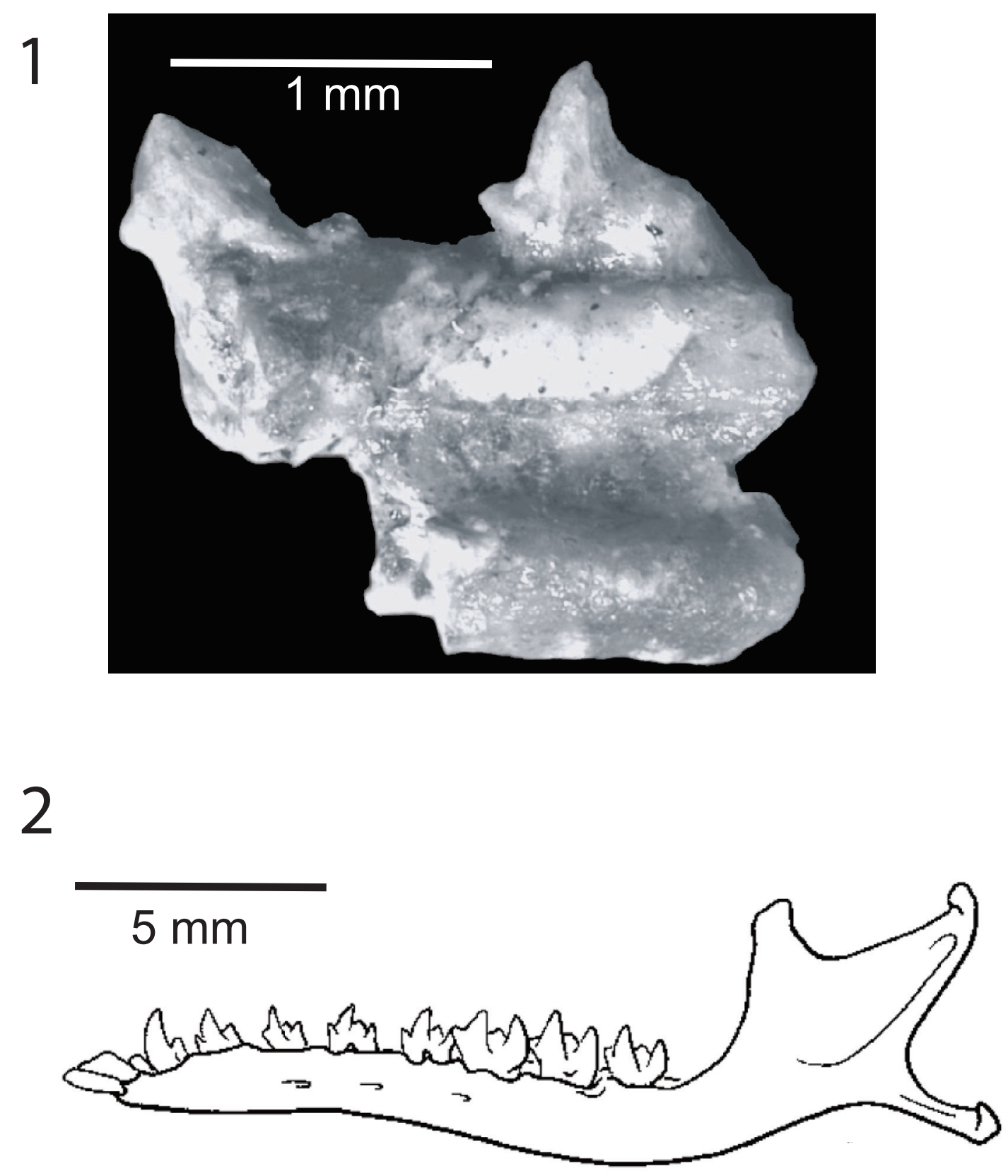

FIGURE 4. 1, Condylura kowalskii, mandible fragment bearing $p 1$ and p2 in lingual view (MF/1006/4, ISEZ-PAN); from Rzebik-Kowalska (2014, figure 1.3). 2, Line drawing of a left mandible of Condylura cristata in labial view, modified from Laerm et al. (2007).

men and the central position of the trochlear medial edge (Figure 3.3-5).

Condylura kowalskii Skoczeń, 1976. The Kazakh specimen is very similar to the Polish species in the overall shape of the humeral shaft (Figures 3.6-7, 4.1). It is almost identical in the trochlear morphology sharing the central position of trochlear medial edge. However, C. kowalskii possesses a minor sulcus wider than the Kazakh condylurine mole (Skoczeń, 1976; Rzebik-Kowalska, 2014).

Condylura izabellae Skoczeń, 1976. The Kazakh specimen differs from the Polish smaller Condylura (Skoczeń, 1976; Rzebik-Kowalska, 2014) for the same features of $C$. kowalskii. 


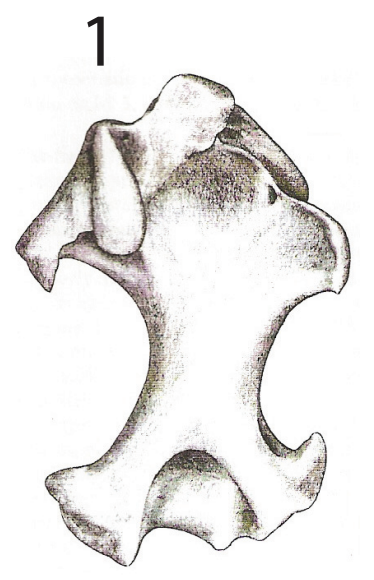

Yanshuella primaeva

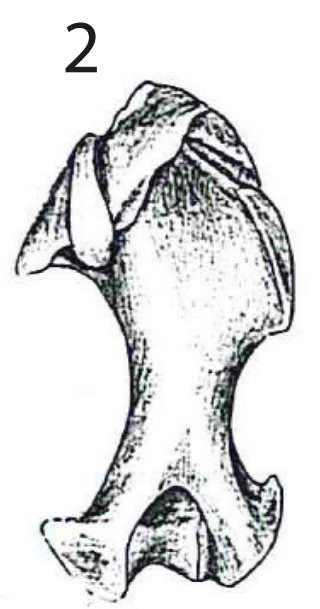

Yunoscaptor scalprum

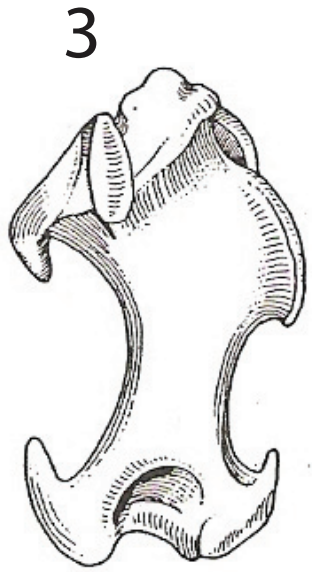

Scapanulus oweni
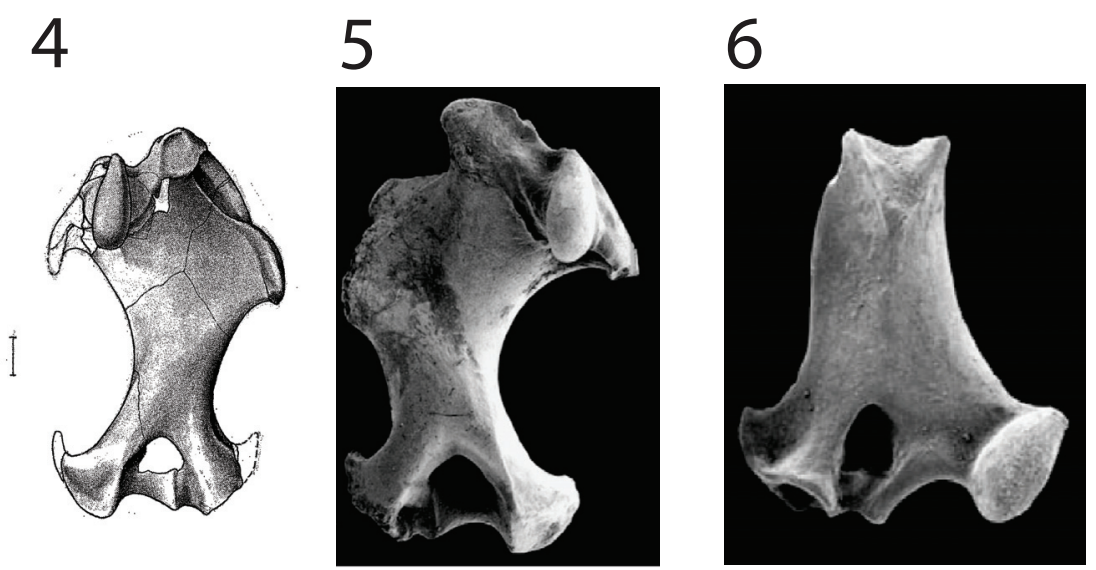

Wilsonius ripafodiator Leptoscaptor robustior Leptoscaptor bavaricum

FIGURE 5. Drawings (1-4) and photographs (5-6) of talpid species humeri in caudal view. 1, Yanshuella primaeva, left humerus (IVPP-6455, IVPP), from Storch and Qiu (1983, figure 39b). 2, Yunoscaptor scalprum, left humerus (IVPP-V9741.38, IVPP), from Storch and Qiu (1991, figure 48b). 3, Scapanulus oweni, left humerus, from Hutchinson (1968). 4, Wilsonius ripafodiator, left humerus (UO-22366, UO), from Hutchinson (1968, figure 55). 5, Leptoscaptor robustior, right humerus (P35-58.6, NHMA), from Ziegler (2003, figure 3B2). 6, Leptoscaptor bavaricum, left humerus (P10610.2, NHMA), from Ziegler (2003, figure 2I).

Condylura cristata Illiger, 1811. The specimen from Kalkaman closely resembles $C$. cristata in the width of both sulci (Hutchinson, 1984). The distal part of the pectoral crest is slightly pronounced, as in C. cristata. The similarities in the trochlea are even more striking, both taxa share the medial edge positioned in the middle of the trochlea. However, the Kazakh specimen possesses the spine of the medial edge of the trochlea medially bended while it is straight in C. cristata (Figures 3.8, 4.2).

Yanshuella primaeava Storch and Qiu, 1983. Condylura sp. possesses a wider greater sulcus and a wider minor sulcus. Further, the distal end of the pectoral crest is less pronounced. Finally, in Yanshuella, the medial edge of the trochlea is medially displaced (as in all other highly fossorial talpids; Storch and Qiu. 1983), while in Condylura $\mathrm{sp}$. is placed in the middle of the trochlea (Figure 5.1).

Yunoscaptor scalprum Storch and Qiu, 1991. The same considerations made for the comparison with Yanshuella hold for Yunoscaptor (Storch and Qiu, 1991). They differ for the trochlea medial edge and, further, for the shape of the supratrochlear fossa (frontal view) (Figure 5.2). 
Scapanulus oweni Thomas, 1912. The differences in the width of both minor and greater sulci are less evident, though $S$. oweni possesses the medially displaced medial edge of the trochlea (Figure 5.3). The last evidence leaves no doubt in excluding close relationships with Scapanulus (Hutchinson, 1968; Storch and Qiu, 1983).

Wilsonius ripafodiator Hutchinson, 1968. The two taxa are almost indistinguishable for the width of both sulci, evidencing the plesiomorphic state of these characters (Hutchinson, 1968). However, the shape of the trochlea is, again, highly different. The Kazakh specimen clearly shows the plesiomorphic features of the humeral distal region, while Mioscalops, possessing the medially displaced medial edge of the trochlea, shows apomorphic characters that reflect a better adaptation to digging (Hutchinson, 1968) (Figure 5.4).

Leptoscaptor robustior Ziegler, 2003. Condylura $\mathrm{sp}$. clearly differs from $L$. robustior in the width of the humeral shaft. In $L$. robustior the minor and greater sulci are narrower, and the medial edge of trochlea is medially displaced as in other highly fossorial moles (Ziegler, 2003) (Figure 5.5).

Leptoscaptor bavaricum Ziegler, 2003. Condylura sp. resembles $L$. bavaricum in the overall slenderness of the humeral shaft and in the width of minor and greater sulci. On the other hand, $L$. bavaricum shows an elliptic supracondylar foramen and the medial edge of the trochlea medially displaced (Ziegler, 2003) (Figure 5.6). These features clearly separate the two taxa.

\section{Remarks}

The humeral fragment from Kalkaman Lake shows close affinities with the other condylurine moles. In particular, the morphology of the trochlear area appears to be distinctive for the genus Condylura. This feature unambiguously separates Condylura from all highly fossorial moles. However, Urotrichini, Neurotrichini and Scaptonyx also show a trochlear medial edge placed in the middle of the trochlea (Hutchinson, 1968; Sánchez-Villagra et al., 2004; Schwerman and Thompson, 2015; Sansalone et al., in press). Despite this evidence, the more robust and wide humeral shaft leaves no doubt about the attribution of the Kazakh specimen to the genus Condylura. Unfortunately, the poor conditions of the proximal region of the humerus do not allow any specific attribution.

\section{DISCUSSION}

\section{Phylogenetic Scenario}

We suggest excluding Achlyoscapter as a stem lineage of Condylurini. Achlyoscapter is known from the middle Miocene of Oregon and late Miocene of Nebraska (Bown, 1980), but only mandibles and teeth have been ascribed to this genus (Hutchinson, 1968; 1984). The unspecialized brachyodont teeth and the absence of humeri do not allow inferring the lifestyle of this genus. Further, the dentition of Achlyoscapter does not bear any of the specializations present in C. cristata. Achlyoscapter lacks molariform lower premolars separated by diastemata. In Achlyoscapter the crista obliqua joins the posterior wall of the trigonid while in Condylura it joins directly the metastylid. Further, C. cristata shows greatly reduced incisors modified into a tweezer-like form used to rapidly and precisely grasp small food items (Catania and Remple, 2005). Catania and Remple (2005) suggested that the unusual dentition of $C$. cristata provide evidences for a long history of selective pressures for feeding on small preys, and that the possible ancestor of Condylura should have characteristics of exaptation for a feeding apparatus capable of increasing the prey detecting and catching speed. Unfortunately none of these features are recognized in $A$. longirostris. Therefore, we suggest to consider Achlyoscapter as Talpidae incertae sedis and as a lineage evolved independently of the Condylurini (Hutchinson, 1968; Klietmann et al., 2014).

The Condylura humerus shows a unique combination of derived and plesiomorphic features. It possesses an enlarged proximal region, where the main digging muscles insert (Gambaryan et al., 2003; Piras et al., 2012; Piras et al., 2015). However, the greater tuberosity and the trochlea resemble that of shrew-moles in their overall shape. Among the fossorial moles Condylura is the sole taxon presenting the trochlear medial edge placed in the middle of the trochlea. This feature is also shared by Urotrichini and, more evidently, by Neurotrichini and Scaptonyx. Modifications of this trait probably influence the articulation of the humerus with the ulna and, hence, the relative position of the forearm (Dobson, 1883; Edwards, 1937; Hutchinson, 1968; Gambaryan et al., 2003). On the other hand, highly fossorial moles (Talpini and Scalopini) all possess the trochlear medial edge medially displaced. Condylura cristata shows a large bicipital notch between the teres tubercle and the lesser tuberosity, where the pectoral ridge 


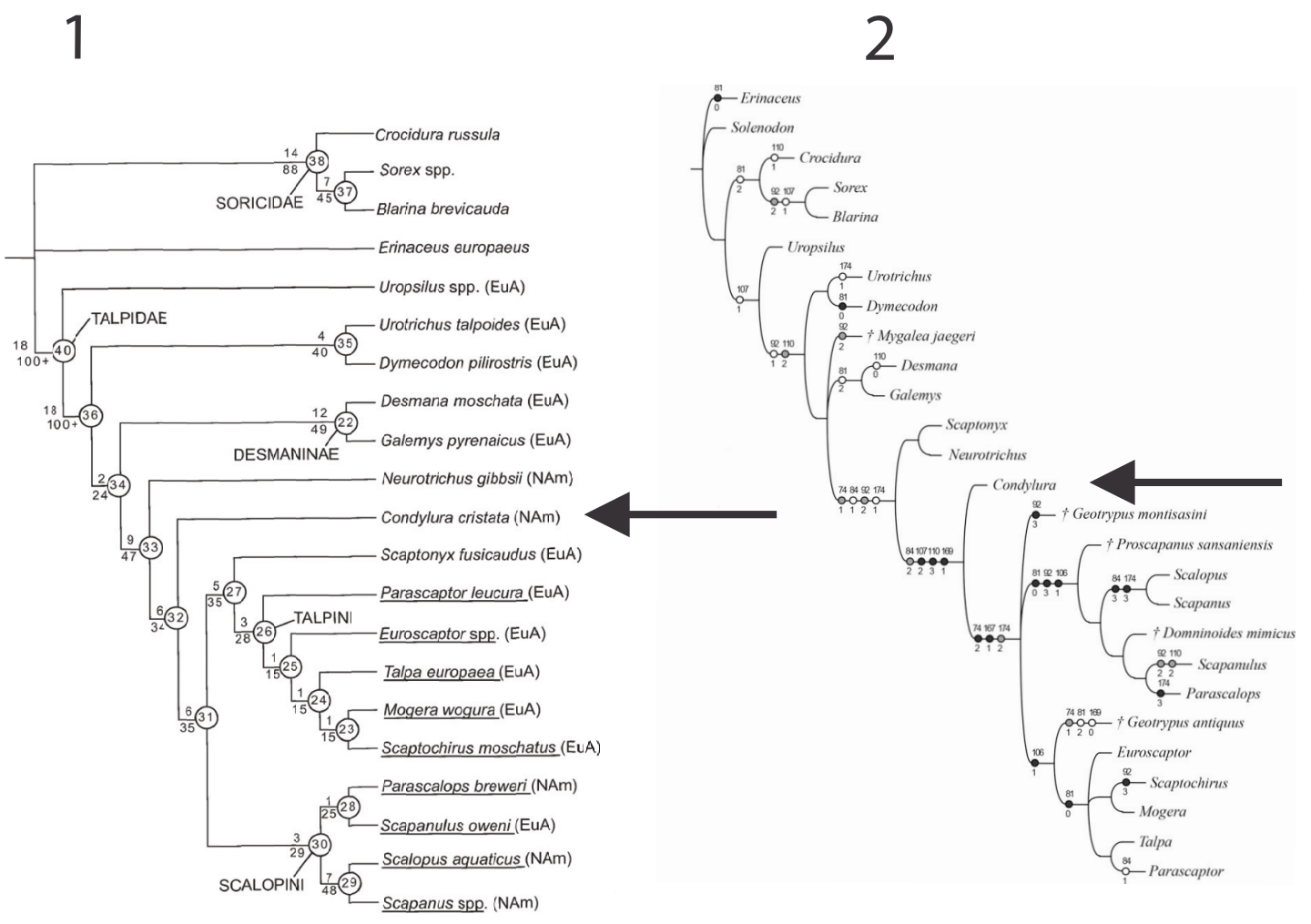

FIGURE 6. 1, Talpidae phylogeny resulting from a parsimony analysis based on 157 discrete morphological characters, modified from Sánchez-Villagra et al. (2006, figure 1). 2, Unconstrained Talpidae phylogeny based on a parsimony analysis (DELTRAN optimization) based on 176 discrete morphological characters, modified from Schwermann and Thompson (2015, figure 16A).

arises. This character is also well evident in Geotrypus antiquus de Blainville, 1840. Schwermann and Martin (2012) evidenced several plesiomorphic features present in $G$. antiquus such as elongate clavicle, distinct metacromion process on the scapula, lack of the terminal process of the ulna and very weak capitular process of the radius. Based on these traits Schwermann and Thompson (2015) interpreted G. antiquus as the least fossorial species among Talpini and suggested that a number of plesiomorphic, shrew-mole-like characters might have been present in the last common ancestor of the highly fossorial moles. In this framework, we provided a stronger support to the hypothesis that Condylura and highly fossorial moles share a shrew-mole-like ancestor. We agree with the phylogenetic hypothesis proposed by Sánchez-Villagra et al. (2006) and Schwermann and Thompson (2015). These authors proposed Condylura as sister clade of Talpinae basing on discrete morphological characters (Figure 6).

\section{Lifestyle}

Some authors suggested that moles adopted the fossorial lifestyle following an aquatic adaptation (Campbell, 1939; Whidden, 1999; Schwerman and Thompson, 2015), while other researchers rejected this view, concluding instead that fossorial and semi-fossorial forms evolved from a cursorial ancestor and that the adaptation to aquatic environment is actually an exaptation (Hickman, 1984; Sánchez-Villagra et al., 2006; Piras et al., 2012; Hooker, 2015). We hypothesize that the shrewmole-like ancestor of Condylura and true moles probably were showing a lifestyle and feeding habit similar to that of extant Urotrichini. Sansalone (2015) reported the Japanese shrew-moles showing two different feeding strategies: 'back-with-grip' and 'bite-and-retreat', depending on whether the prey is either underground or on the ground, respectively. The 'back-with-grip' feeding is faster and probably safer (startled shrew-moles usually abandon prey; Imaizumi, 1979), therefore underground feeding could have contributed to promote, together with the other advantages of the subterra- 
nean ecotope (Nevo, 1979), the evolution of the specialized fossorial lifestyle observed in true moles. According to these evidences we prefer to consider the semi-aquatic lifestyle of Condylura as an autapomorphy and as a case of exaptation (Sánchez-Villagra et al., 2006; Piras et al., 2012; Hooker, 2015).

\section{Palaeoecology}

Condylura cristata shows a unique mixed lifestyle. This species is adapted to burrowing but also has a good performance as a diver (Mclntyre et al., 2002). The 22 fleshy appendages surrounding the nostrils can be compared to a visual organ as the tendrils intensively touch substrate or food items (Catania et al., 1999; see Figure 1). The star-like appendages also allow Condylura to "smell underwater": although the star-like structure is not a chemoreceptor itself, it helps the star-nosed mole to blow small air bubbles onto objects or scent trails. These bubbles are then drawn back into the nostrils so that odorant molecules in the air bubbles are wafted over the olfactory receptors (Catania, 2006). According to Skoczeń (1976), we hypothesize that the lifestyle of the extinct $C$. kowalskii and C. izabellae was very similar to that of the extant North American species. The mandible of $C$. cristata is more elongated and slender than that of other talpids (Barrow and MacLeod, 2008). It appears that development of a unique nasomaxillary articulation and nasolabial musculature associated with the starry-nose relates to the evolution of the star-like tendrils. This has shifted the plane of the anterior teeth, creating the unique diastemas between the premolars and lengthened the horizontal ramus (Barrow and MacLeod, 2008; see Figure 4.2). In this context, the presence of a mandibular fragment, bearing p1 and p2 with an evident diastema (Figure 4.1), from Węże 1 locality, strongly supports the hypothesis that both $C$. kowalskii and $C$. izabellae possessed the star-like appendages. The $\mathrm{p} 1$ and $\mathrm{p} 2$ of $C$. kowalskii are almost identical in shape to those of C. cristata, probably reflecting a similar adaptation to a fast feeding.

This should be considered as the first, albeit indirect, evidence of the presence of this highly specialized organ in the fossil record. Unfortunately, the lack of dental remains attributed to the cf. Condylura sp. from Oregon and to Condylura sp. from Kazakhstan does not allow inferring the presence of the star-like appendages. However, basing on the palaeobiogeographical hypothesis exposed in the following paragraph, we suggest the possibility that this organ was already developed in the ancestors of Condylurini.

Skoczen (1976) hypothesized that the Polish fossil Condylura spp. lived in an environment with conditions similar to that of the extant species. In particular, species associated to aquatic environments (amphibians, water turtles and mammals) are well represented in Węże 1 and Rębielice Królewskie $1 \mathrm{~A}$ and 2 localities (Rzebik-Kowalska, 1971). Among these semi-aquatic forms, the presence of Desmana and Galemys is of particular interest. Skoczen (1976) hypothesized that the Polish species were outcompeted by desmans (Desmaninae), which were larger, had stronger dentition and already lived in Europe at that time, and likely occupied the same ecological niche (Rzebik-Kowalska, 2014). In this framework, we hypothesize that the cf. Condylura sp. from Oregon experienced a similar fate. In the Hemphillian of Oregon the presence of Gaillardia thomsoni Matthew, 1932, a talpid species well adapted to aquatic environment (Hutchinson, 1968), is reported. The cf. Condylura sp. might have been outcompeted by $G$. thomsoni due to its larger size and stronger dentition. By contrast, C. cristata, colonizing the East Coast, probably did not experience the competitive pressure exerted by other semi-aquatic lipotyphlans and was able to survive until today.

The presence of two Polish Condylura species, highly different in size (C. kowalskii: larger; $C$. izabellae: smaller), suggests that a speciation process could have occurred in response to eco-evolutionary constraints, such as inter-specific competition and the ability to exploit low productive habitats. Size differences between sympatric sister species is a very common pattern in Talpidae and has been extensively documented for several highly fossorial and shrew-mole taxa (Loy et al., 1996; Loy and Capanna, 1998; van Cleef-Roders and van den Hoek Ostende, 2001; van den Hoek Ostende, 2001; Yokohata, 2005; Bego et al., 2008; Klietmann et al., 2014; Sansalone, 2015; Sansalone et al., 2016).

\section{Palaeobiogeography}

The presence of a Condylura in the middle Miocene of Asia opens new scenarios about the origin of this genus. The specimen from Kalkaman Lake represents the earliest record for the genus, thus supporting the hypothesis of a Eurasian origin for Condylura (Skoczeń, 1976). Further, the fossil from Kazakhstan would bridge the geographical gap between the Polish Pliocene Condylura spp. 


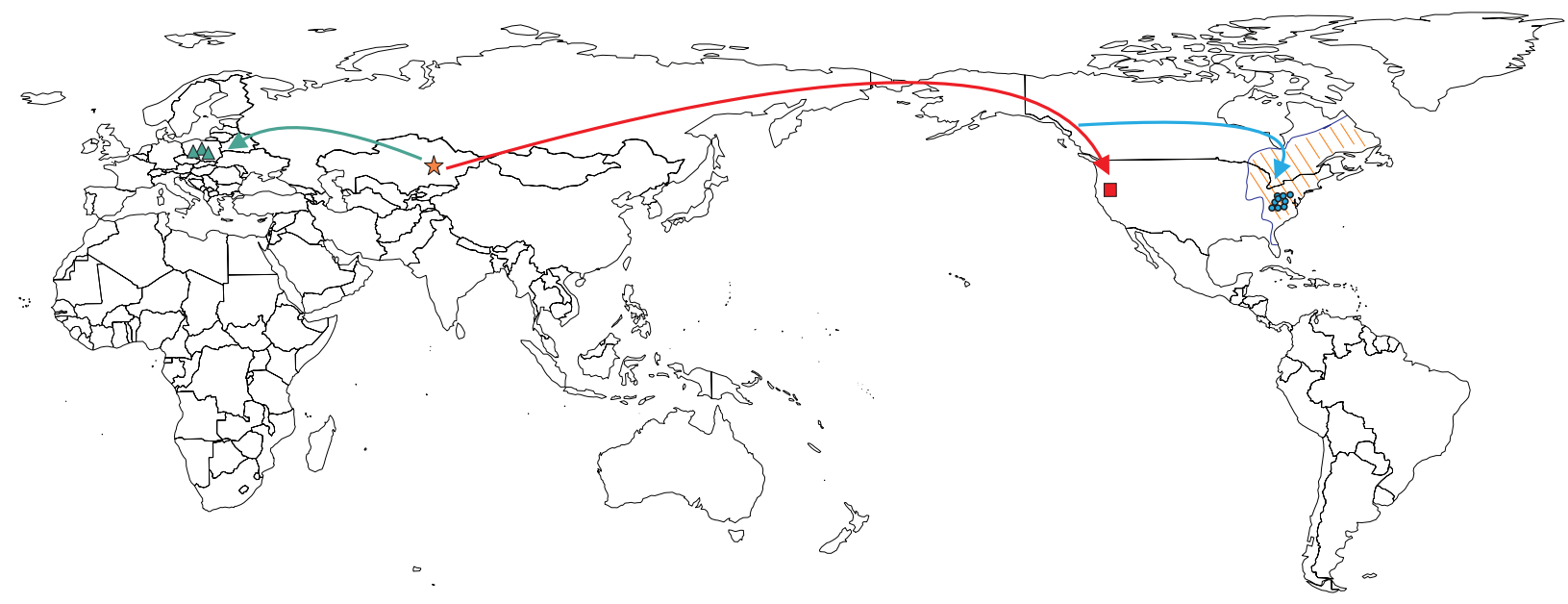

FIGURE 7. Map showing Condylura fossil bearing localities and a possible palaeobiogeographical scenario. The orange striped area represents the present distribution of the extant $C$. cristata. The orange star represents Condylura $\mathrm{sp}$. (middle Miocene locality of Kalkaman Lake, Kazakhstan). The red square represents cf. Condylura sp. (late Miocene locality of Malheur River, Oregon, USA). The green triangles represent C. kowalskii and C. izabellae (Pliocene Polish localities). The blue circles represent the late Pleistocene-Holocene localities of C. cristata.

and the North American ones (Figure 7). Sansalone et al. (2016), reviewing the neurotrichine fauna from the same Polish localities, revealed the link between the European and Asiatic shrewmoles. They showed as Neurotrichini originated in Asia and then followed two colonization routes: one toward Eastern Europe and the other leading to North America. In this framework, we hypothesize that Condylura spread following a similar pattern. Condylura members could have colonized North America during the early middle Hemphillian. In fact, during the Hemphillian different dispersal waves occurred between Asia and North America. Mammals migrating from Eurasia to North America included Mustelids (Eomellivora and Plesiogulo), Felids (Machairodus), Procyonids (Simocyon), Arvicolids (several genera) and Bovids (Neotragoceros) (Webb, 1985, 1998; Baskin, 1998a, 1998b; Martin, 2008). In particular, during the early middle Hemphillian, the migration of forms linked to the aquatic environment such as Castor is reported (Flynn and Jacobs, 2008). In North America, Condylura members could have followed two colonization routes: one toward the West Coast and the other toward the East Coast (Figure 7). This view is supported by the presence of cf. Condylura sp. in the late Miocene of Oregon and by the presence of Condylura fossil remains in several Pleistocene localities within or just south of the present range of C. cristata (Petersen and Yates, 1980; Hutchinson, 1984; Gunnell et al., 2008).

On the European side, Condylura members could have spread from Asia through Eastern
Europe during the early Pliocene. At that time several talpid genera colonized Poland from Asia (Rzebikia, Quyania, Parascalops; Rzebik-Kowalska, 2014; Sansalone et al., 2016).

However, in the very unlikely case that cf. Condylura sp. from Oregon could belong to the Mascall formation (middle Miocene 14-15 m.y.a., Barsovian) a different scenario would open to us. The specimen described by Hutchinson (1984) should be considered as the earliest record of the genus. In this case we could hypothesize that Condylura originated in the West Coast of North American and subsequently colonized Asia during the middle Miocene and, then, spread through Eastern Europe during the early Pliocene. It is well accepted that faunal inter-changes between Asia and North America are often asymmetrical. In fact, a large number of immigrants from Old World constituted a significant component of local communities in North America. On the contrary, few mammals of New World origin did the same in Asia (Wang et al., 2013). Despite the evident unbalance in the faunal exchange between the two continents, we recognize two possible colonization events during which Condylura members could have spread through Asia. The first one could have occurred during the middle Miocene (end of MN6 $\sim 13$ m.y.a.). At that time the migration into Asia, from North America, of the mustelids Leptarctus and Sthenictis is recorded (Qiu, 2003; Tseng et al., 2009). Another possible migration event could correspond with the arrival in the Old World of "Hipparion" (early late Miocene MN7-8, 11.5 m.y.a.) that 
could have crossed the Bering Land Bridge during the TB3.1 sea level lowstand (Garcés et al., 1997; Tseng et al., 2009).

\section{CONCLUSIONS}

The re-appraisal of the Condylura sp. in the middle Miocene of Kazakhstan gives a stronger support to the hypothesis of a Eurasiatic origin of the genus Condylura. Further, this fossil contributes to bridging the geographic gap between the Eastern Europe Condylura spp. and the North American ones. We provided a stronger support to the hypothesis that see Condylura as sister clade of Talpinae and that both clades originated from a semi-fossorial shrew-mole like ancestor.

\section{ACKNOWLEDGEMENTS}

We are grateful to B. Rzebik-Kowalska from ISEZ PAN, Krakow, Poland, that allowed G. Sansalone to access the Polish Talpidae collection. We are in debt to $\mathrm{S}$. Bell for providing us the reference reporting the specimen from Kazakhstan. We want to thank P. Tleuberdina for providing us information about the specimen from Kazakhstan. We are also grateful to P. Jenkins and to R Portella from NHM, London, UK; to U. Goehlich from NHMW, Wien, Austria; M. Rummel from NHMA, Augsburg, Germany; to P. Holroyd from UCMP, Berkeley, California, USA; to Z. Qiu from IVPP, Beijing, China that allowed G. Sansalone to visit their Talpidae collections. We are also grateful to two anonymous referees for their useful and meticulous comments that significantly improved the manuscript quality. G. Sansalone received support from the SYNTHESYS Project (http://www.synthesys.info), which is financed by European Community Research Infrastructure Action under the FP7 "Capacities" Program (GB-TAF-2095 and AT-TAF-3415).

\section{REFERENCES}

Barrow, E. and MacLeod, N. 2008. Shape variation in the mole dentary (Talpidae, Mammalia). Zoological Journal of the Linnean Society, 153:187-211.

Baskin, J.A. 1998a. Evolutionary trends in the late Miocene hyena-like dog Epicyon (Carnivora, Canidae). In Tomida, Y., Flynn, L.J., and Jacobs, L.L. (eds.), Advances in Vertebrate Paleontology and Geochronology: National Science Museum, Tokyo, Monographs, 14:191-214.

Baskin, J.A. 1998b. Mustelidae, p. 153-174. In Janis, C.M., Scott, K.M., and Jacobs, L.L. (eds.), Evolution of Tertiary Mammals of North America, Vol. 1: Terrestrial Carnivores, Ungulates, and Ungulatelike Mammals, Cambridge University Press, Cambridge.
Bego, F., Kryštufek, B., Paspali, G., and Rogozi, E. 2008. Small terrestrial mammals of Albania: annoted list and distribution. Italian Journal of Mammalogy, 19:83-101.

Bown, T.M. 1980. The fossil Insectivora from Lemoyne Quarry (Hash Hollow Formation, Hemphillian), Keith County, Nebraska. Nebraska Academy of Science, Transactions, 8:99-122.

Cabria, M.T., Rubines J., Gomez-Moliner B., and Zardoya, R. 2006. On the phylogenetic position of a rare Iberian endemic mammal, the Pyrenean desman (Galemys pyrenaicus). Gene, 375:1-13.

Campbell, B. 1939. The shoulder anatomy of the moles. A study in phylogeny and adaptation. The American Journal of Anatomy, 64:1-39.

Campbell, K.L., Mclntyre, I.W., and MacArthur, R.A. 2000. Postprandial heat increment does not substitute for active thermogenesis in cold-challenged starnosed moles (Condylura cristata). Journal of Experimental Biology, 203:301-310.

Catania, K.C. 1995. A comparison of the Eimer's organs of three North American moles: The hairy-tailed mole (Parascalops breweri), the star-nosed mole (Condylura cristata), and the eastern mole (Scalopus aquaticus). Journal of Comparative Neurology, 354:150160.

Catania, K.C. 2005. Star nosed moles. Current Biology, 15:R863-R864.

Catania, K.C. 2006. Olfaction: underwater 'sniffing' by semi-aquatic mammals. Nature, 444:1024-1025.

Catania, K.C. 2012a. Evolution of brains and behavior for optimal foraging: A tale of two predators. Proceedings of the National Academy of Sciences, 109:10701-10708.

Catania, K.C. 2012b. A nose for touch. The Scientist, 26(9). http://www.the-scientist.com/?articles.view/articleNo/32505/title/A-Nose-forTouch/

Catania, K.C. and Kaas, J.H. 1996. The unusual nose and brain of the star-nosed mole. Bioscience, 46:578-586.

Catania, K.C., Northcutt, R.G., and Kaas, J.H. 1999. The development of a biological novelty: a different way to make appendages as revealed in the snout of the star-nosed mole Condylura cristata. Journal of Experimental Biology, 202:2719-2726.

Catania, K.C. and Remple, F.E. 2005. Asymptotic prey profitability drives star-nosed moles to the foraging speed limit. Nature, 433:519-522.

Crumpton, N. and Thompson, R.S. 2013. The holes of moles: osteological correlates of the trigeminal nerve in Talpidae. Journal of Mammalian Evolution, 20:213225.

de Blainville, H.M.D. 1840. Osteographie des mammifères insectivores (Talpa, Sorex et Erinaceus L.), p. 1-115. In de Blainville, H.M.D. (ed.), Osteographie des mammifères. Volume 1. Baillère, Paris. 
Dobson, G.E. 1883. A Monograph of the Insectivora, Systematic and Anatomical Part II. John van Voorst, London.

Edwards, L.F. 1937. Morphology of the forelimb of the mole (Scalops aquaticus, L.) in relation to its fossorial habits. Ohio Journal of Science, 37:20-41.

Eimer, T. 1871. Die Schnauze des Maulwurfs als Tastwerkzeug. Archiv für mikroskopische Anatomie, 7:181-191.

Fischer von Waldheim, G. 1814. Zoognosia tabulis synopticis illustrate Vol. 3. Nicolai Sergeidis Vsevolozsky, Moscow.

Flynn, L.J. and Jacobs, L.L. 2008. 23. Castoroidea, p. 391-405. In Janis, C.M., Gunnell, G.F., and Uhen, M.D. (eds.), Evolution of Tertiary Mammals of North America, Volume 2: Small Mammals, Xenarthrans, and Marine Mammals, Cambridge University Press, Cambridge.

Gambaryan, P., Gasc, J.P., and Renous, S. 2003. Cinefluorographical study of the burrowing movements in the common mole, Talpa europaea (Lipotyphla, Talpidae). Russian Journal of Theriology, 1:91-109.

Garcés, M., Cabrera, L., Agustí, J., and Parés, J. M. 1997. Old World first appearance datum of "Hipparion" horses: Late Miocene large-mammal dispersal and global events. Geology, 25(1):19-22.

Gill, T.N. 1875. Synopsis of insectivorous mammals. Bulletin of United States Geological and Geographical Survey, 1:91-120.

Gould, E., McShea, W., and Grand, T. 1993. Function of the star in the star-nosed mole, Condylura cristata. Journal of Mammalogy, 74:108-116.

Guilday, J.E. 1979. The star nosed mole/a Polish connection. Carnegie Magazine, 53:18-25.

Guilday, J.E., Martin, P.S., and McCrady, A.D. 1964. New Paris No 4: A Pleistocene cave deposit in Bedford County, Pennsylvania. Bulletin of the National Speleological Society, 26:121-194.

Gunnel, G.F., Bown, T.M., Hutchinson, J.H., and Bloch, J.I. 2008. 7. Lipotyphla, p. 89-125. In Janis, C.M., Gunnell, G.F., and Uhen, M.D. (eds.), Evolution of Tertiary Mammals of North America, Vol. 2: Small Mammals, Xenarthrans, and Marine Mammals, Cambridge University Press, Cambridge.

Hamilton, W.J. 1931. Habits of the star-nosed mole, Condylura cristata. Journal of Mammalogy, 12:345355.

Hickman, G.C. 1984. Swimming ability of talpid moles, with particular reference to the semi-aquatic CondyIura cristata. Mammalia, 48:505-514.

Hooker, J.J. 2015. Skeletal adaptations and phylogeny of the oldest mole Eotalpa (Talpidae, Lipotyphla, Mammalia) from the UK Eocene: the beginning of fossoriality in moles. Palaeontology, 59:195-216.

Hutchinson, J.H. 1968. Fossil Talpidae (Insectivora, Mammalia) from the later Tertiary of Oregon. Bulletin of the Natural History Museum of Oregon, 11:1-120.

Hutchinson, J.H. 1974. Notes on type specimens of European Miocene Talpidae and a tentative classifi- cation of Old World Tertiary Talpidae (Insectivora: Mammalia). Geobios, 7:211-256.

Hutchinson, J.H. 1976. The Talpidae (Insectivora, Mammalia): Evolution, Phylogeny, and Classification. University of California Press, Berkeley, California.

Hutchinson, J.H. 1984. cf. Condylura (Mammalia, Talpidae) from the Late Tertiary of Oregon. Journal of Vertebrate Paleontology, 4:600-601.

Hutterer, R. 2005. Order Soricomorpha, p. 220-311. In Wilson, D.E. and Reeder, D.A.M. (eds.), Mammal Species of the World. $3^{\text {rd }}$ Edition. The Johns Hopkins University Press, Baltimore.

Illiger, C.D. 1811. Prodromus Systematis Mammalium et Avium Additis Erminis Zoographicis Uttriusque Classis. Salfeld, Berlin. (in Latin)

Imaizumi, Y. 1979. Hunting methods in relation to hunting situations in Japanese shrew-mole, Urotrichus talpoides. Annotationes Zoologicae Japonenses, 52:212-224.

Klietmann, J., Nagel, D., Rummel, M., and van den Hoek Ostende, L.W. 2014. A gap in digging: the Talpidae of Petersbuch 28 (Germany, Early Miocene). Paläontologische Zeitschrift, 89(3):563-592.

Laerm, J., Chapman, B.R., and Ford, W.M. 2007. Star nosed mole Condylura cristata, p.113-116. In Trani, M.K., Ford, W.M., and Brian, R. (eds.), The Land Manager's Guide to Mammals of the South. Forest Service, United States Department of Agriculture, Washington D.C., USA.

Linnaeus, C. 1758. Systema naturae per regna tria naturae, secundum classes, ordines, genera, species, cum characteribus, differentiis, synonymis, locis. Vol. 1: Regnum animale. 10th edition, reformata. Laurenti Salvii, Holmiae. (In Latin)

Loy, A., Di Martino, S., and Capolongo, D. 1996. Patterns of geographic variation of Talpa romana Thomas: preliminary results derived from a geometric morphometric approach. Mammalia, 60:77-89.

Loy, A. and Capanna, E. 1998. A parapatric contact area between two species of moles (genus Talpa): character displacement investigated through the geometric morphometric of skull. Acta Zoologica Academiae Scientiarum Hungaricae, 44:151-164.

Lychev, G.F. 1963. Neogenovye mlekopitaiushie Malogo Kalkamana (Pavlodarskoe Priirtyshe). Materialy po istorii fauny i flory Kazakhstana, 4:12-21. (In Russian)

Martin, R.D. 2008. 28. Arvicolidae, p. 480-498. In Janis, C.M., Gunnell, G.F., and Uhen, M.D. (eds.), Evolution of Tertiary Mammals of North America Vol. 2: Small Mammals, Xenarthrans, and Marine Mammals. Cambridge University Press, Cambridge.

Marzban, H., Hoy, N., Buchok, M., Catania, K.C., and Hawkes, R. 2014. Compartmentation of the cerebellar cortex: adaptation to lifestyle in the star-nosed mole Condylura cristata. The Cerebellum, 14:106118. 
Matthew, W.D. 1932. New fossil mammals from the Snake Creek quarries. American Museum Novitates, 540:1-8.

Mclntyre, I.W., Campbell, K.L., and MacArthur, R.A. 2002. Body oxygen stores, aerobic dive limits and diving behaviour of the star nosed mole (Condylura cristata) and comparisons with non aquatic talpids. Journal of Experimental Biology, 205:45-54.

McKenna, M.C. and Bell, S.K. 1997. Classification of Mammals Above the Species Level. Columbia University Press, New York.

Mirzaie Ataabadi, M., Liu, L., Eronen, J.T., Bernor, R., and Fortelius, M. 2013. Continental Scale Patterns in Neogene Mammal Community Evolution and Biogeography: A Europe-Asia Perspective, p. 629-655. In Wang, X., Flynn, L.J., and Fortelius, M. (eds.), Fossil Mammals of Asia. Columbia University Press, New York.

Motokawa, M. 2004. Phylogenetic relationships within the family Talpidae (Mammalia: Insectivora). Zoological Journal of the Linnean Society, 263:147-157.

Nevo, E. 1979. Adaptive convergence and divergence of subterranean mammals. Annual Review of Ecology and Systematics, 20:269-308.

Parmalee P.W., Oesch R.D., and Guilday J.E. 1969. Pleistocene and Recent vertebrate faunas from Crankshaft Cave, Missouri. Illinois State Museum Reports of Investigations, 14:1-37.

Petersen, K.E. and Yates, T.L. 1980. Condylura cristata. Mammalian Species, 129:1-4.

Piras, P., Sansalone, G., Colangelo, P., Teresi, L., Kotsakis, T., and Loy, A. 2012. Testing convergent and parallel adaptations in talpids humeral mechanical performance by means of Geometric Morphometrics and Finite Element Analysis. Journal of Morphology, 273:696-711.

Piras, P., Sansalone, G., Teresi, L., Moscato, M., Profico, A., Eng, R., Cox, T.C., Loy, A., Colangelo, P., and Kotsakis, T. 2015. Digging adaptation in insectivorous subterranean eutherians. The enigma of Mesoscalops montanensis unveiled by geometric morphometrics and finite element analysis. Journal of Morphology, 276:1157-1171.

Qiu, X. 2003. Dispersals of Neogene carnivorans between Asia and North America. Bulletin of the American Museum of Natural History, 279:18-31.

Rust, C.C. 1966. Notes on the star-nosed mole (Condylura cristata). Journal of Mammalogy, 47:538.

Rzebik-Kowalska, B. 1971. The Pliocene and Pleistocen insectivores (Mammalia) of Poland I. Erinaceidae and Desmaninae. Acta Zoologica Cracoviense, 16:435-461.

Rzebik-Kowalska, B. 2014. Revision of the Pliocene and Pleistocene Talpidae (Soricomorpha, Mammalia) of Poland. Palaeontologia Electronica, 17:1-26.

Sánchez-Villagra, M.R., Menke, P.R., and Geisler, J.H. 2004. Patterns of evolutionary transformation in the humerus of moles (Talpidae, Mammalia): a character analysis. Mammal Study, 29:163-170.
Sánchez-Villagra, M.R., Horovitz, I., and Motokawa, M. 2006. A comprehensive morphological analysis of talpid moles (Mammalia) phylogenetic relationship. Cladistics, 22:59-88.

Sansalone, G. 2015. Evolution of hypsodonty reveals a long-standing ecological separation in the Japanese shrew-moles. Journal of Zoology, 297:146-155.

Sansalone, G., Kotsakis, T., and Piras, P. 2016. New systematic insights about Plio-Pleistocene moles from Poland. Acta Palaeontologica Polonica, 61:221-229.

Schwermann, A.H. and Martin, T. 2012. A partial skeleton of Geotrypus antiquus (Talpidae, Mammalia) from the Late Oligocene of the Enspel Fossillagerstätte in Germany. Paläontologische Zeitschrift, 86:409-439.

Schwermann, A.H. and Thompson, R.S. 2015. Extraordinarily preserved talpids (Mammalia, Lipotyphla) and the evolution of fossoriality. Journal of Vertebrate Palaeontology, 35(4):e934828. doi: dx.doi.org/10.1080/02724634.2014.934828

Shinohara, A., Campbell, K.L., and Suzuki, H. 2003. Molecular phylogenetic relationships of moles, shrew moles, and desmans from the new and old worlds. Molecular Phylogenetics and Evolution, 27:247-258.

Signore, A.V., Stetefeld, J., Weber, R.E., and Campbell, K.L. 2012. Origin and mechanism of thermal insensitivity in mole hemoglobins: a test of the 'additional'chloride binding site hypothesis. The Journal of Experimental Biology, 215:518-525.

Skoczeń, S. 1976. Condylurini Dobson, 1883 (Insectivora, Mammalia) in the Pliocene of Poland. Acta Zoologica Cracoviensia, 21:291-314.

Skoczeń, S. 1993. New records of Parascalops, Neurotrichus and Condylura (Talpinae, Insectivora) from the Pliocene of Poland. Acta Theriologica, 38:125137.

Storch, G. and Qiu, Z.D. 1983. The Neogene mammalian faunas of Ertemte and Harr Obo in Inner Mongolia (Nei Mongol), China. - 2. Moles - Insectivora: Talpidae. Senckenbergiana Lethaea, 64:89-127.

Storch, G. and Qiu, Z.D. 1991. Insectivores (Mammalia: Erinaceidae, Soricidae, Talpidae) from the Lufeng hominoid locality, Late Miocene of China. Geobios, 24:601-621.

Thomas, O. 1912. On a collection of small mammals from the Tsin-ling Mountains, Central China, presented by Mr. G. Fenwick Owen to the National Museum. Annals and Magazine of Natural History. ser. 8, 10:395-403.

Tleuberdina, P.A. 1988. Osnovye mestonakhoshdenya gipparionovoi fauny Kazakhstana i ikh biostratigraficheskaya korrelyatsiya. Materialy po istorii fauny $i$ flory Kazakhstana, 10:38-73. (In Russian)

Tleuberdina, P.A. 1989. O vozraste fauny pozvonochnykh iz serozelenykh glin Pavlodarskogo Priirtyshya. Kainotsoi Sibiri I Cevero-vostoka SSSR. Trudy Instituta geologii i geografii, Sibirskoe Otdelenie Akademii Nauk SSSR, 668:59-66. (In Russian) 
Tleuberdina, P. and Forsten, A. 2001. Anchitherium (Mammalia, Equidae) from Kazakhstan, Central Asia. Geobios, 34:449-456.

Tleuberdina, P.A., Volkova, V.S., Gutieva, N., Kaipova, G., Lushaeva, T., Lychev, G., Pita, O., Tiutkova, A., and Chikvadze, V. 1993. Fauna pozvonochnykh Kalkamana (Pavlodarskoe Priirtyshe). Materialy po istorii fauny i flory Kazakhstana. Faunisticheskie i floristicheskie kompleksy mezotsoiya i kainotsoiya Kazakhstana, 12:132-158. (In Russian)

Tseng, Z.J., O'Connor, J.K., Wang, X., and Prothero, D.R. 2009. The first old world occurrence of the North American mustelid Sthenictis (Mammalia, Carnivora). Geodiversitas, 31(4):743-751.

van Cleef-Roder, J.T. and van den Hoek Ostende, L.W. 2001. Dental morphology of Talpa europaea and Talpa occidentalis (Mammalia: Insectivora) with a discussion of fossil Talpa in the Pleistocene of Europe. Zoologische Mededelingen, 75:51-68.

van den Hoek Ostende, L.W. 2001. Insectivore fauna from the Lower Miocene of Anatolia - part 5: Talpidae. Scripta Geologica, 122:1-45.

Waddell, P.J., Okada, N., and Hasegawa, M. 1999. Towards resolving the interordinal relationships of placental mammals. Systematic Biology, 48:1-5.

Wang, X., Flynn, L.J., and Fortelius, M. 2013. Fossil Mammals of Asia: Neogene Biostratigraphy and Chronology. New York, Columbia University Press.
Webb, S.D. 1985. Main pathways of mammalian diversification in North America, p. 201-217. In Stehli, F.G. and Webb, S.D. (eds.), The Great American Biotic Interchange. Plenum Press, New York.

Webb, S.D. 1998. 34. Cervidae and Bovidae, p. 508510. In Janis, C.M., Scott, K.M., and Jacobs, L.L. (eds.), Evolution of Tertiary Mammals of North America Vol. 1: Terrestrial carnivores, ungulates, and ungulatelike mammals. Cambridge University Press, Cambridge.

Whidden, H.P. 1999. The evolution of locomotor specializations in moles. American Zoologist, 39:135A.

Whidden, H.P. 2000. Comparative myology of moles and the phylogeny of the Talpidae (Mammalia, Lipotyphla). American Museum Novitates, 3294:1-53.

Yates, T.L. and Moore, D.W. 1990. Specification and evolution in the family Talpidae (Mammalia, Insectivora), p. 1-22. In Nevo, E. and Reig, O.A. (eds.), EvoIution of Subterranean Mammals at the Organismal and Molecular Levels. Liss, New York.

Yokohata, Y. 2005. A brief review of the biology on moles in Japan. Mammal Study, 30:25-30.

Ziegler, R. 2003. Moles (Talpidae) from the late Middle Miocene of South Germany. Acta Palaeontologica Polonica, 48:617-648. 


\section{APPENDIX}

List of material used for comparisons.

Condylura cristata. NHM-3.11.5, humerus and mandible. NHM-3.11.6, humerus and mandible. NHM-1.7.4, mandible. NHM-12.12.1, mandible. NHM-1.25.2, mandible. NHM-7.7.2659, mandible. NHM-7.7.132, mandible. NHM7.7.2792, mandible. NHM-12.5.3, mandible. NHM-1.7.2, mandible. NHM-1.7.3, mandible. Natural History Museum NHM, London, UK. 62567, mandible. NHMW.

Condylura izabellae. MF/1007/01, humerus. ISEZ-PAN.

Condylura kowalskii. MF/1006/4, mandibular fragment bearing p1-p2. MF/1006/16, humerus. MF/ $1006 / 18$, humerus. MF/1006/21, humerus. MF/1006/22, humerus. MF/1006/23, humerus. ISEZ-PAN.
Leptoscaptor bavaricum. P10-610.2, humerus. Ptb68_1962, humerus. Ptb68_1962b, humerus. Ptb68_1962c, humerus. NHMA.

Leptoscaptor robustior. P35-58.6, humerus. NHMA.

Scapanulus oweni. Drawings from Hutchinson, 1968; Storch and Qiu, 1983.

Mioscalops ripafodiator. UCMP-70140b, humerus. UCMP-V70140a, humerus. UCMPV70140d, humerus. University of California Museum of Palaeontology, UCMP, Berkeley, California, USA.

Yanshuella primaeva. IVPP-6455, humerus. IVPP6456, humerus. IVPP.

Yunoscaptor scalprum. IVPP-V-9741.38, humerus. IVPP. 